\title{
Soil fertility status of some villages in Kalakankar block of plains of central agroclimatic zone of U.P.
}

\author{
Prashant Upadhyay, Pawan Sirothia, N. K. Singh and Manoj Kumar Singh
}

Received : 09.02.2018; Revised : 03.05.2018; Accepted : 17.05.2018

\section{MEMBERS OF RESEARCH FORUM:}

Corresponding author :

Prashant Upadhyay, Department of Soil Science, Mahatma Gandhi

Chitrakoot Gramodaya

Vishwvidyalya, Chitrakoot, Satna (M.P.) India
Co-authors :

Pawan Sirothia, N. K. Singh and Manoj Kumar Singh, Department of Soil Science, Mahatma Gandhi Chitrakoot Gramodaya Vishwvidyalya, Chitrakoot, Satna (M.P.) India

\section{Summary}

The current study on the status of the soil fertility in Kalakankar block of dist. Pratapgarh U.P. by total $36(0-15)$ soil samples. Soil sample (were collected from): three villages namely Alapur, Shahabad and Sahijani of Kalakankar block District Pratapgarh. The organic carbon content of all the three villages varied from low to medium. The available $\mathrm{N}$ content of all the three villages was found to be low and it was found to be in positive co-relation with the carbon content of the lands. The available $\mathrm{N}$ content was higher in medium land type of Shahabad in comparison to similar land type of other two villages. The available $\mathrm{P}$ content of all soil in all the three villages was moderate. However, the P content of the Alapur village was higher than other two villages because of the higher content of organic matter. The available $\mathrm{K}$ contents of all the soil of all the three villages was moderate to high and especially in the Sahijani village it was highest. This is the good indication for the high yield of various vegetable, fruits and tuber crops with a high amount of $\mathrm{K}$. The $\mathrm{S}$ content was found to be comparatively higher in the medium land soil of all three villages, The available $\mathrm{Zn}$ content was moderate to rich in all types of soil, however, upland of all three village were rich in $\mathrm{Zn}$ content in comparison to medium and low land of the village. Bo content was higher in all types of soil of three villages. The various result obtained from the different soil tests gave information about the nutrients status of the soil, under study and on the basis of these findings, a balanced recommendation of fertilizers and manures to various crops can be made, that will help in increasing the productivity of different food crops.

Key words : Soil fertility, Organic carbon, Pratpgarh, Nutrients

How to cite this article : Upadhyay, Prashant, Sirothia, Pawan, Singh, N.K. and Singh, Manoj Kumar (2018). Soil fertility status of some villages in Kalakankar block of plains of central agroclimatic zone of U.P. Asian J. Soil Sci., 13 (1) : 30-35 : DOI : 10.15740/HAS/AJSS/13.1/30-35. Copyright@ 2018: Hind Agri-Horticultural Society. 